\title{
MÔ PHỎNG MỘT SỐ KICH BẢN TRÀN DẦU KHU VỰC ĐẢO CỒN CỎ
}

\author{
Trần Anh Tú ${ }^{*}$, Lê Đức Cường \\ Viện Tài nguyên và Môi trường Biển-Viện Hàn lâm Khoa học và Công nghệ Việt Nam \\ E-mail: tuta@imer.ac.vn
}

Ngày nhận bài: 2-1-2014

\begin{abstract}
TÓM TẮT: Đảo tiền tiêu Cồn Cỏ đóng vai trò quan trọng trong chiến luợc phát triển kinh tế và an ninh quốc phòng của nước ta. Nhu cầu năng lương-dầu mỏ trên thế giới ngày càng tăng, kèm theo sụ vận chuyển dầu trên biển cũng tăng theo. Với vị trí gần tuyến đường vận chuyển dầu tù Trung Đông về Đông Bắc Á, đảo Cồn Cỏ sẽ chịu nhiều ảnh hưởng khi có sụ cố tràn dầu xảy ra. Với kỹ thuật lưới lồng của mô hình Delft3D, một số kịch bản tràn dầu (100 tấn) theo các hướng gió khác nhau của khu vục đảo Cồn Cỏ đã được mô phỏng. Kết quả tính toán với truờng hợp gió huớng Đông Bắc vệt dầu ảnh hưởng tù 9-14 ngày; truờng hơp gió huoóng Nam vệt dầu ảnh hưởng tù 6-9 ngày và truờng hơp gió huớng Tây Nam vệt dầu ảnh huơong tù 12-14 ngày. Kết quả nghiên cứu sẽ là co sở tham khảo cho các đơn vị quản lý môi truờng biển và các ngành liên quan.
\end{abstract}

Tù̀ khóa: Đảo tiền tiêu, tràn dầu.

\section{MỞ ĐÀ̀}

Biển và đại dương có vai trò quan trọng đối với sự sống của loài người nói chung và Việt Nam nói riêng. Việc phát triển nhiểu ngành kinh tế biển khác nhau như hàng hải, thủy sản, khai thác dầu khí, du lịch, ... các quá trình đó đều tạo ra các nguồn gây ô nhiễm biển. Thực tế cho thấy các vụ ô nhiễm biển do dầu thường gây ra các thiệt hại rất lớn, diện tích rất rộng (1 tấn dầu có thể loang phủ một diện tích tới $12 \mathrm{~km}^{2}$ mặt nước, 1 gam dầu có thể làm bẩn 2 tấn nước [1]). Biển Đông nói chung và biển Việt Nam nói riêng là bồn chứa các loại dầu thải từ nhiều nguồn gốc khác nhau (rò rỉ từ khai thác, vận chuyển, tai nạn trên biển và nguồn dầu thải đưa ra từ lục địa). Nhiều tài liệu đã nói đến vai trò rất lớn của nguồn dầu thải từ các hoạt động trên tuyến hàng hải quốc tế đi qua hải phận nước ta. Kết quả từ các trạm trắc môi trường trên biển do Cục Bảo vệ Môi trường quản lý từ năm 1995 đến nay đều cho thấy xu hướng hàm lượng dầu gây ô nhiễm trong nước biển có xu hướng tăng dần từ bờ ra khơi xa, có liên quan đến hoạt động tàu thuyền trên các tuyến hàng hải. Để giảm thiểu ảnh hưởng đến môi trường biển do tràn dầu gây ra, nhiều công trình đã được nghiên cứu về vệt dầu đối với Biển Đông và khu vực vịnh Bắc Bộ. Tuy nhiên, chưa có nhiều công trình nghiên cứu tràn dầu ảnh hưởng đến các đảo tiền tiêu thuộc vùng biển Việt Nam. Đảo Cồn Cỏ (tỉnh Quảng Trị) là một trong những đảo tiền tiêu của Việt Nam, nằm tại cửa vịnh Bắc Bộ, gần tuyến vận chuyển dầu từ Trung Đông về Đông Bắc Á [3]. Với vị trí này, đảo Cồn Cỏ chịu nhiều ảnh hưởng khi có sự cố tràn dầu xảy ra. Để có được bức tranh chung về sự lan truyền của vệt dầu theo các hướng gió khác nhau, công trình này đã sử dụng mô hình Delft3d mô phỏng một số kịch bản tràn dầu khu vực đảo Cồn Cỏ.

\section{TÀI LIỆU VÀ PHƯƠNG PHÁP}

\section{Tài liệu}

Để thực hiện công trình này, số liệu đường bờ (dùng để tạo lưới tính toán) của khu vực 
nghiên cứu được số hóa lại từ các bản đồ địa hình UTM tỷ lệ 1: 25.000 do Cục Đo đạc Bản đồ xuất bản (2005), đây là những bản đồ với hệ tọa độ nhà nước VN-2000. Số liệu độ sâu (hình 2) được lấy từ nguồn cơ sở dữ liệu GEBCO -1/8 (General Bathymetric Chart of the Ocean) của Trung tâm tư liệu hải dương học vương quốc Anh-BODC (British Oceanographic Data Centre) [4]. Số liệu về dao động mực nước trên các biên mở phía biển được tạo từ mô đun TIDE từ hằng số điều hòa lấy từ bộ hằng số điều hòa toàn cầu FES2004 của dự án Topex/ Poseidon với độ phân giải 1/8 độ và được hiệu chỉnh với dữ liệu đo đạc tại các trạm hải văn trong vịnh Bắc Bộ như Hòn Dấu, Hòn Ngư, Đà Nẵng, ...

Các tài liệu về khí tượng, hải văn, chất lượng nước được lấy từ đề tài VAST 06.03/ 12-13.

\section{Phương pháp}

Để mô phỏng quá trình tràn dầu khi có sự cố tràn dầu xảy ra, đã sử dụng mô đun Delft3DPART trong bộ mô hình Delft3D của Hà Lan. Ngoài ra, mô đun Delft3D-FLOW đã được sử dụng để cung cấp thông tin thủy động lực của khu vực nghiên cứu.

Delft3D-PART là module nằm trong bộ mô hình Delft3D, có chức năng tính toán và dự báo sự biến động, phân bố về hàm lượng của vật chất theo thời gian bằng phương pháp Monte Carlo [2].

Đối với việc tính toán tràn dầu, với giả thiết rằng dầu được đưa vào thủy vực từ một nguồn liên tục hoặc tức thời, phạm vi lan truyền của dầu được xác định bằng phương trình (Fay và Hoult, 1971):

$$
R_{0}=\frac{k_{2}^{2}}{k_{1}}\left(\frac{V_{0}^{5} g\left(\frac{\rho_{w}-\rho_{0}}{\rho_{w}}\right)}{v_{w}^{2}}\right)^{1 / 12}
$$

Trong đó: $V_{0}$ : thể tích ban đầu của dầu tràn $\left(\mathrm{m}^{3}\right) ; \rho_{w}$ - tỷ trọng của dầu $\left(\mathrm{kg} / \mathrm{m}^{3}\right) ; \rho_{0}$ : tỷ trọng của nước $\left(\mathrm{kg} / \mathrm{m}^{3}\right) ; \mathrm{g}$ - hằng số hấp dẫn $\left(\mathrm{m} / \mathrm{s}^{2}\right) ; v_{w}$ : độ nhớt của nước; $\mathrm{k}_{1}, \mathrm{k}_{2}$ : hằng số Fay.

Tốc độ lan truyền của dầu $\mathrm{Q}\left(\mathrm{kg} / \mathrm{m}^{2} / \mathrm{s}\right)$ được xác định theo phương trình sau:

$$
\begin{gathered}
Q=\int_{d \min }^{d \max } Q(d) d d \\
Q(d)=C^{\prime \prime} D_{e}^{0.57} F_{w c} N(d) d^{3} \\
N(d)=N_{0} d^{-2.3} \\
D_{e}=0.0034 \rho_{w} g H_{0} / \sqrt{2} \\
H_{0}=\frac{0.234 U_{w}^{2}}{g} \\
F_{w c}=\frac{f_{w}}{t_{p}} ; t_{p}=8.13 U_{w} / g \\
f_{w}=\max \left(0.0 ; 0.032\left(U_{w}-5.0\right)\right)
\end{gathered}
$$

Với: Q(d) là tốc độ lan truyền trên một đơn vị với giọt dầu đường kính $\mathrm{d}\left(\mathrm{kg} / \mathrm{m}^{2} / \mathrm{s}\right) ; \mathrm{d}_{\text {min }}$-đường kính giọt dầu nhỏ nhất $(\mathrm{m}) ; \mathrm{d}_{\max }$-đường kính giọt dầu lớn nhất $(\mathrm{m})$; $\mathrm{C}$ " -hằng số hiệu chỉnh (phụ thuộc vào từng loại dầu); $\mathrm{N}(\mathrm{d})$-hàm phân bố kích thước của phần tử dầu; $\mathrm{N}_{0}$-hàm phân bố tiêu chuẩn; $\mathrm{D}_{\mathrm{e}}$-tiêu hao của năng lượng sóng trên một đơn vị diện tích bề mặt $\left(\mathrm{J} / \mathrm{m}^{2}\right) ; \mathrm{F}_{\mathrm{wc}}$-số sóng đổ trên một chu kỳ sóng; $\mathrm{t}_{\mathrm{p}}$-chu kỳ sóng cực đại (s); $\mathrm{U}_{\mathrm{w}}$-vận tốc gió $(\mathrm{m} / \mathrm{s}) ; \mathrm{f}_{\mathrm{w}}$-phần biển được bao phủ bởi sóng bạc đầu [2].

\section{Triển khai mô hình}

Thiết lập miền và luơoi tính

Khu vực nghiên cứu không có số liệu quan trắc trên biên, vì vậy cần xây dựng các điều kiện biên. Điều đó chỉ có thể thực hiện tính toán trên miền lớn hơn (toàn bộ Biển Đông), sau đó trích xuất số liệu tại ranh giới khu vực nghiên cứu.

Miền tính bao gồm hai khu vực: a) Khu vực Biển Đông, được giới hạn trong phạm vi tính 
toán có tọa độ $99^{\circ} \mathrm{E}$ đến $121^{\circ} \mathrm{E}$ và $01^{\circ} \mathrm{N}$ đến $24^{0} \mathrm{~N}$. Các biên là mực nước dự báo theo hằng số điều hòa thủy triều tại: eo Đài Loan, eo Bashi và eo Malaca, b) Khu vực đảo Cồn Cỏ được thể hiện trên hình 1 . Miền tính được chia thành $251 \times 251$ ô lưới; kích thước các ô lưới: $\Delta \mathrm{y}=\Delta \mathrm{x}=100 \mathrm{~m}$.

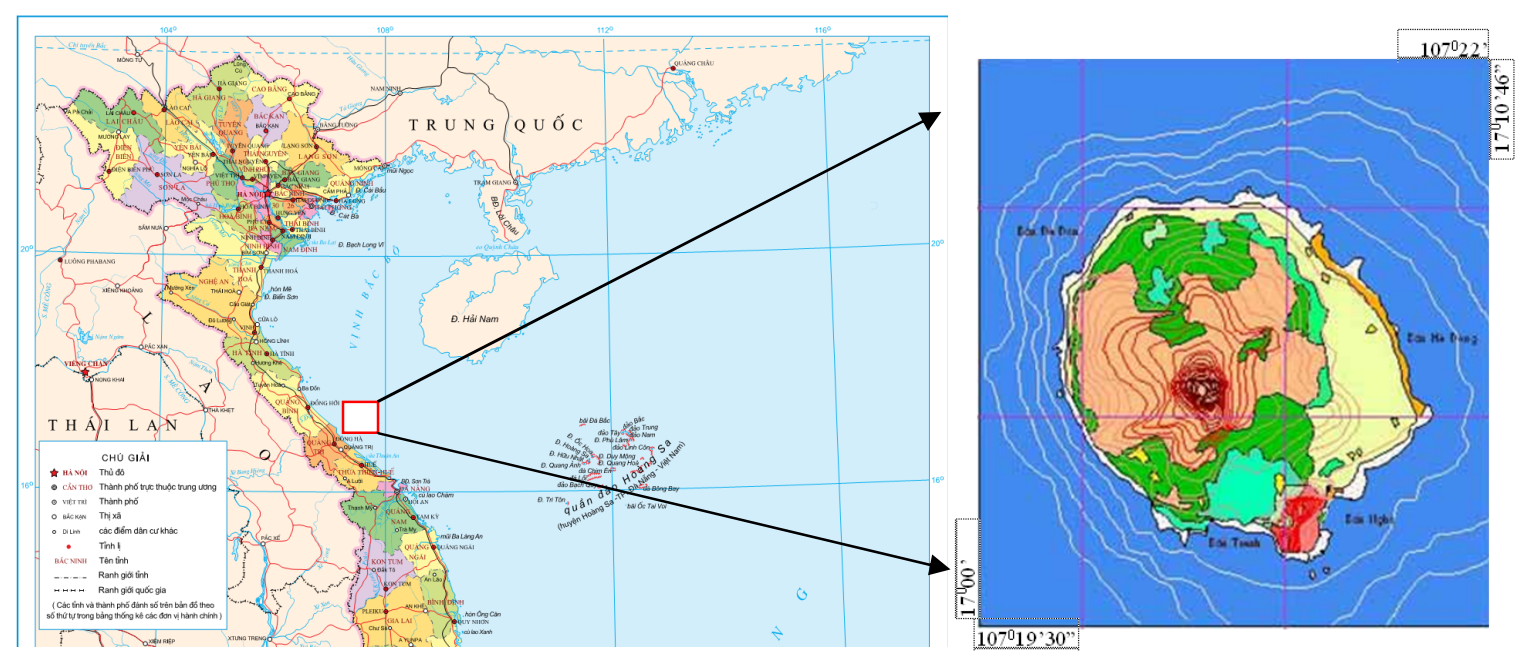

Hình 1. Sơ đồ khu vực nghiên cứu

\section{Điều kiện biên}

Tại biên lỏng: mực nước thủy triều được tính toán theo hằng số điều hòa thủy triều. Tại biên cứng: cho điều kiện không chảy qua (vận tốc pháp tuyến $=0$ ). Kết quả tính toán thủy động lực cho toàn bộ Biển Đông sau đó được truy xuất là điều kiện biên cho mô hình chi tiết đối với khu vực nghiên cứu. Kỹ thuật lưới lồng trong Delft-3D được áp dụng.

\section{KẾT QUẢ MÔ PHỎNG}

\section{Hiệu chỉnh mô hình}

Sau nhiều lần tính toán, so sánh vận tốc và hướng dòng chảy giữa số liệu tính toán và thực đo (đề tài VAST 06.03/12-13) tại phía Tây đảo Cồn Cỏ được thể hiện lần lượt trên hình 2 và hình 3. Với hệ số tương quan của thành phần vận tốc có giá trị là 0,73 . Như vậy, việc hiệu chỉnh cho kết quả tốt, có thể sử dụng bộ các tham số hiệu chỉnh này để đưa vào các tính toán khác.

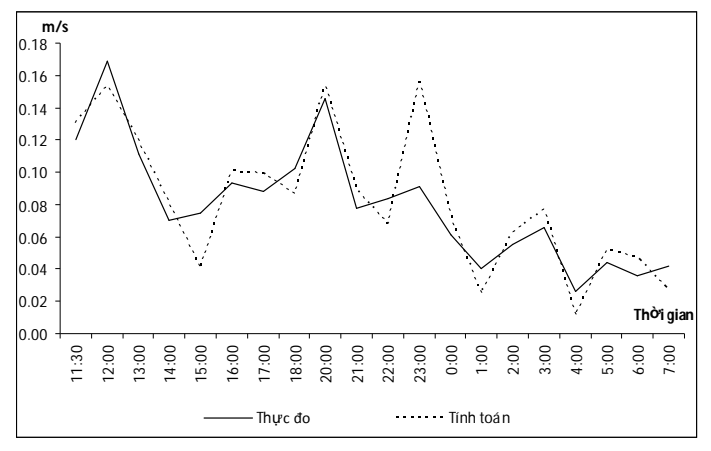

Hình 2. So sánh vận tốc $(\mathrm{m} / \mathrm{s})$ dòng chảy tính toán với thực đo tại phía Tây đảo Cồn Cỏ

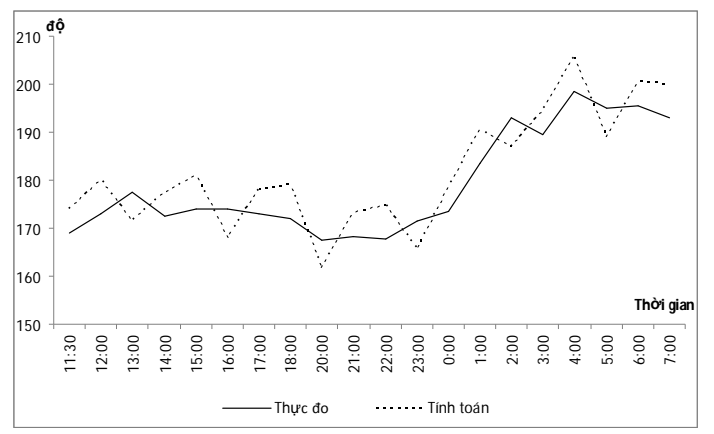

Hình 3. So sánh hướng $\left(^{0}\right)$ dòng chảy tính toán với thực đo tại phía Tây đảo Cốn Cỏ 


\section{Dòng chảy}

Trường dòng chảy khu vực đảo Cồn Cỏ là tổng hợp của các thành phần dòng triều, dòng chảy gió gây ra. Trong đó, dòng triều tuần hoàn có vai trò quan trọng quyết định đến tính chất chung của dòng chảy tổng hợp.

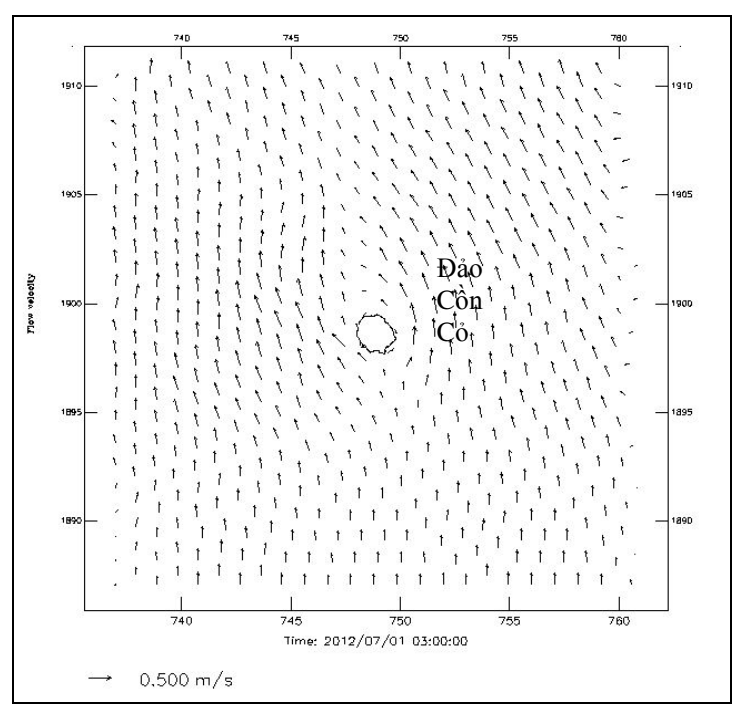

Hình 4. Trường dòng chảy khu vực đảo Cồn Cỏ khi triều lên (gió Đông Bắc)

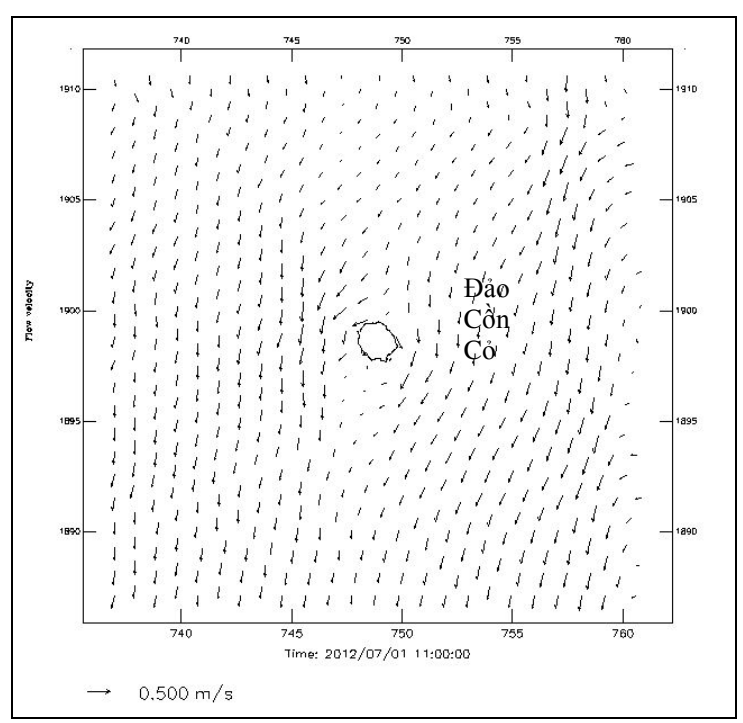

Hình 5. Trường dòng chảy khu vực đảo Cồn Cỏ khi triều xuông (gió Đông Bắc)

Tốc độ dòng chảy lớn nhất là $0,55 \mathrm{~m} / \mathrm{s}$ trong thời kỳ giữa pha triều lên và triều xuống, hướng dòng chảy chiếm ưu thế là Bắc, Tây Bắc trong pha triều lên và Nam, Tây Nam trong pha triều xuống. Vào thời điểm chân triều và đỉnh triều hướng dòng chảy bị phân tán mạnh về hướng, tốc độ dòng chảy đạt giá trị lớn nhất tại khu vực ven đảo $(0,5 \mathrm{~m} / \mathrm{s})$. Trong thời kỳ chuyển pha triều dòng chảy thường có hướng Tây với tốc độ vào khoảng $0,1-0,3 \mathrm{~m} / \mathrm{s}$. Tại khu vực sát ven bờ đảo hướng dòng chảy có $x u$ hướng song song với đường bờ, trong thời kỳ giữa pha triều lên (xuống) dòng chảy ở khu vực sát ven bờ phía Bắc (Nam) đảo có giá trị khá nhỏ $(0,1-0,2 \mathrm{~m} / \mathrm{s})$ và phân tán mạnh về hướng (hình 4,5 ).

\section{Tràn dầu}

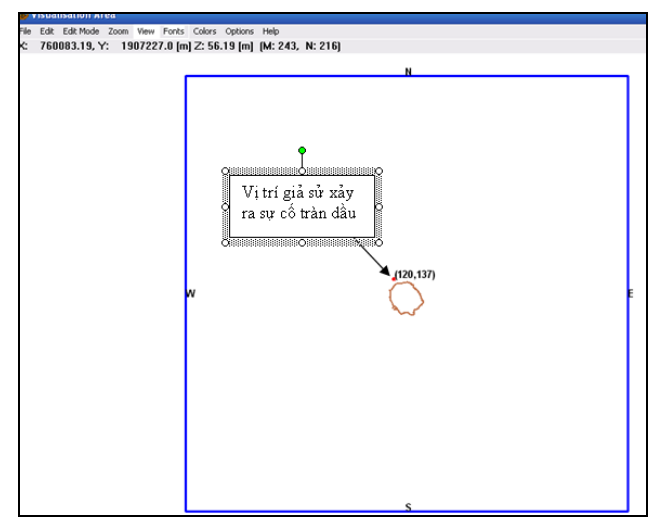

Hình 6. Sơ đồ vị trí giả định xảy ra sự cố tràn dầu

Kịch bản chạy mô hình lan truyền dầu do sự cố tràn dầu tại khu vực phía Bắc Tây Bắc của đảo Cồn Cỏ đối với loại dầu $\mathrm{DO}$ (tỷ trọng là $850 \mathrm{~kg} / \mathrm{m}^{3}$, độ nhớt là $8 \times 10^{-6} \mathrm{~m}^{2} / \mathrm{s}$ ơ $20^{\circ} \mathrm{C}$ ). Với giả thiết khối lượng dầu tràn là 100 tấn theo các kịch bản xảy ra trùng với thời điểm pha triều lền và pha triều xuống với các hướng gió khác nhau $\left(45^{\circ}, 180^{\circ}\right.$ và $\left.225^{\circ}\right)$. Trong trường hợp dầu $\mathrm{DO}$, thành phần dầu bám đáy được xem như không đáng kể, do tỷ trọng nhẹ nên dạng tồn tại nổi trên mặt nước là chính. Lượng dầu nổi được xác định là lớp dầu mỏng phía trên cùng bề mặt cột nước có đơn vị tính là $\mathrm{kg} / \mathrm{m}^{2}$, loại dẩu rơi xuống đáy và bám vào đất có cùng đơn vị là $\mathrm{kg} / \mathrm{m}^{2}$, loại dầu lơ lửng trong cột nước do kết quả của quá trình xáo trộn và nhũ tương hóa có đơn vị tính là $\mathrm{kg} / \mathrm{m}^{3}$. Loại dầu trong nước là sản phẩm của quá trình xáo trộn nước bề mặt (do gió, sóng gây nên) đủ mạnh làm cho dầu nổi đi vào trong nước, mặt khác các hạt lơ lửng trong nước cũng tạo điều 
kiện cho quá trình nhũ tương hóa diễn ra nhanh hơn. Trong điều kiện tốc độ gió nhỏ, sóng nhỏ thì quá trình dầu đi vào nước không đáng kể.

Vị trí giả sử xảy ra sự cố tràn dầu được thể hiện như hình 6 (tọa độ dạng UTM-WGS84: $748.217,38 \mathrm{~m} ; 1.899 .652,80 \mathrm{~m}$. Trong các kịch bản tính toán, tốc độ gió khoảng $4 \mathrm{~m} / \mathrm{s}$ nên lớp nước bề mặt ít xáo trộn (gây ra bởi gió và sóng), loại dầu $\mathrm{DO}$ sau khi tràn ra chủ yếu tồn tại ở dạng dầu nổi.

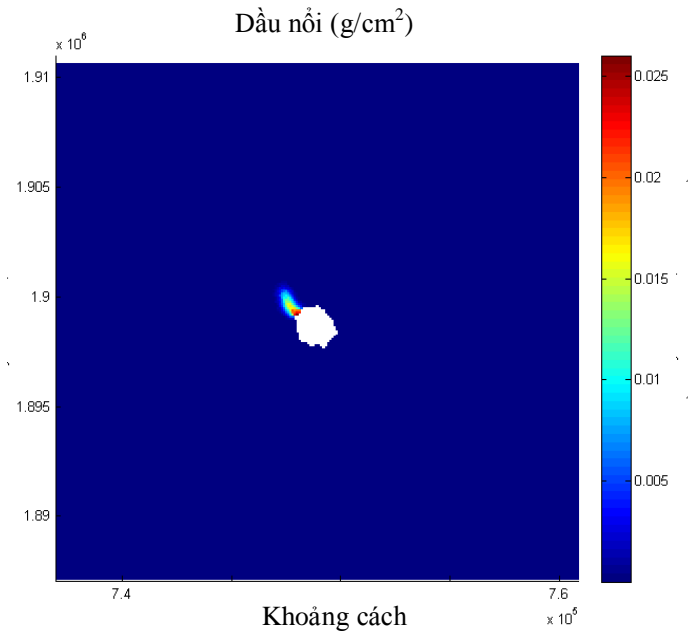

(a)
Gió hướng Đông Bắc: với kịch bản sự cố tràn dầu $\mathrm{DO}$ xảy ra khi trường gió có hướng là Đông Bắc với tốc độ là $4 \mathrm{~m} / \mathrm{s}$, khối lượng dầu tràn là 100 tấn. Vệt dầu chỉ ảnh hưởng trong phạm vi tính toán khoảng 9 ngày khi sự cố xảy ra vào thời điểm pha triều lên và 14 ngày khi sự cố xảy ra vào thời điểm pha triều xuống. Các đặc trưng (hàm lượng, hướng di chuyển, vùng ảnh hưởng) của vệt dầu biến đổi theo thời gian được thể hiện trong hình 7 và bảng 1 .

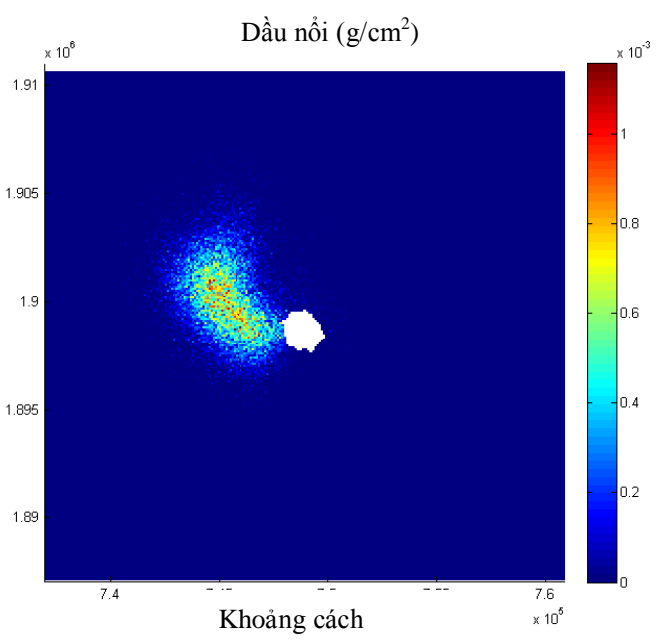

(b)

Hình 7. Sự cố tràn dầu (hướng gió Đông Bắc, pha triều lên) sau 1 giờ (a) và sau 6 giờ (b)

Bảng 1. Các đặc trưng của vệt dầu với trường hợp tính cho hướng gió Đông Bắc $\left(45^{0}\right)$

\begin{tabular}{|c|c|c|c|c|}
\hline TT & $\begin{array}{l}\text { Thò̀i } \\
\text { gian }\end{array}$ & $\begin{array}{l}\text { Hướng di chuyển của } \\
\text { vệt dầu }\end{array}$ & $\begin{array}{l}\text { Hàm lượng dầu } \\
\max \left(\mathbf{k g} / \mathrm{m}^{2}\right)\end{array}$ & Vùng ảnh hưởng \\
\hline \multicolumn{5}{|c|}{ Sụ̂ cố xảy ra trùng với thời điểm pha triều lên } \\
\hline 1 & $1 \mathrm{~h}$ & Về phía Tây & $0,025-0,026$ & Từ vị trí tràn dầu mở rộng về phía Tây Tây Bắc của đảo \\
\hline 2 & $6 \mathrm{~h}$ & Về phía Tây Tây Nam & $1,2 \times 10^{-3}$ & $\begin{array}{l}\text { Mở rộng từ phía Tây Bắc đến Tây Tây Nam cách từ bờ ra } \\
\text { phía ngoài khoảng } 5 \text { km }\end{array}$ \\
\hline 3 & $12 \mathrm{~h}$ & Về phía Tây Nam & $5,1 \times 10^{-4}$ & $\begin{array}{l}\text { Toàn bộ góc } 1 / 4 \text { mở rộng từ phía Tây đến phía Nam của } \\
\text { đảo }\end{array}$ \\
\hline 5 & $36 \mathrm{~h}$ & $\begin{array}{l}\text { Mở rộng lên phía Tây } \\
\text { Bắc và Phía Đông } \\
\text { Nam }\end{array}$ & $1,8 \times 10^{-4}$ & $\begin{array}{l}\text { Khu vực phía Đông Bắc của đảo cách bờ khoảng } 8 \text { km } \\
\text { không bi ảnh hưởng, còn lại các khu vực khác đều bi ảnh } \\
\text { hưởng }\end{array}$ \\
\hline \multicolumn{5}{|c|}{ Sụ̂ cố xảy ra trùng với thời điểm pha triều xuống } \\
\hline 8 & $12 \mathrm{~h}$ & Lên phía Bắc & $5,5 \times 10^{-4}$ & $\begin{array}{l}\text { Góc } 1 / 4 \text { phía Tây Nam khu vực tính toán, một phần lên phía } \\
\text { Bắc từ bờ ra phía ngoài khoảng } 6 \mathrm{~km} \text {, một phần sang phía } \\
\text { Đông của đảo-từ bờ ra phía ngoài khoảng } 3 \mathrm{~km} \text {. }\end{array}$ \\
\hline 9 & $24 \mathrm{~h}$ & Lên phía Bắc & $3,0 \times 10^{-4}$ & $\begin{array}{l}\text { Toàn bộ } 1 / 2 \text { phạm vi tính toán - từ phía Bắc-Tây-Nam của } \\
\text { đảo; một phần nhỏ mở rộng sang phía Đông của đảo }\end{array}$ \\
\hline 10 & $36 \mathrm{~h}$ & Phía Bắc, phía Đông & $2,2 \times 10^{-4}$ & Ảnh hưởng hấu hết phạm vi tính toán \\
\hline
\end{tabular}


Gió hướng Nam: với kịch bản sự cố tràn dầu DO xảy ra khi trường gió có hướng là $\mathrm{Nam}$ với tốc độ là $4 \mathrm{~m} / \mathrm{s}$, khối lượng dầu tràn là 100 tấn. Vệt dầu chỉ ảnh hưởng trong phạm vi tính toán khoảng 9 ngày khi sự cố xảy ra vào thời điểm pha triều lên và 6 ngày khi sự cố xảy ra vào thời điểm pha triều xuống. Các đặc trưng (hàm lượng, hướng di chuyển, vùng ảnh hưởng) của vệt dầu biến đổi theo thời gian được thể hiện trong hình 8 và bảng 2 .

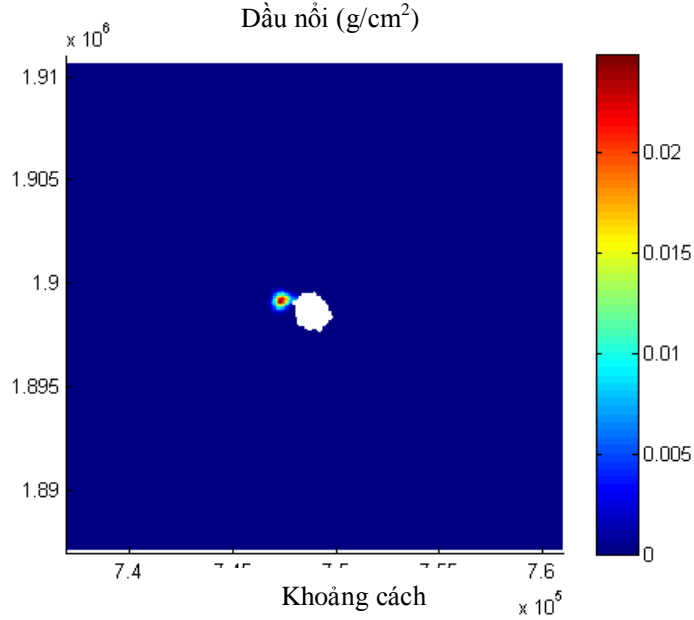

(a)

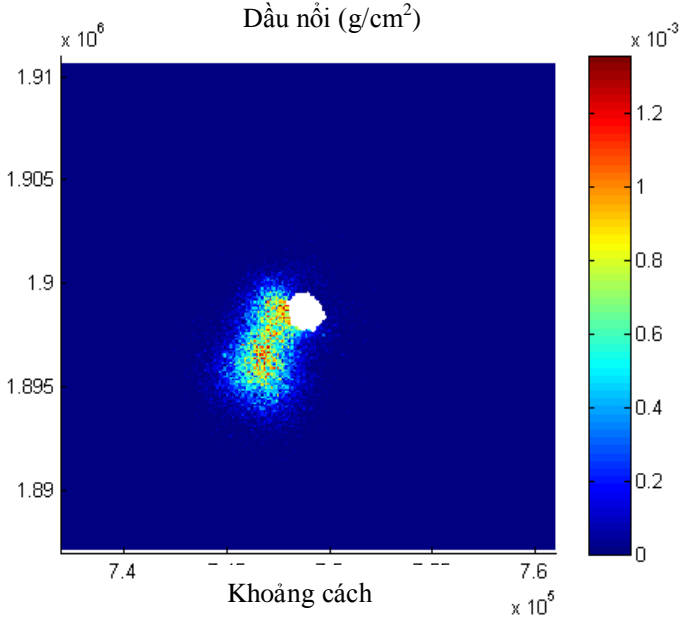

(b)

Hình 8. Sự cố tràn dầu (hướng gió Nam, pha triều xuống) sau 1 giờ (a) và sau 6 giờ (b)

Bảng 2. Các đặc trưng của vệt dầu với trường hợp tính cho hướng gió $\mathrm{Nam}\left(180^{\circ}\right)$

\begin{tabular}{|c|c|c|c|c|}
\hline TT & $\begin{array}{l}\text { Thời } \\
\text { gian }\end{array}$ & $\begin{array}{l}\text { Hướng di chuyển } \\
\text { của vệt dầu }\end{array}$ & $\begin{array}{l}\text { Hàm lượng dầu } \\
\max \left(\mathrm{kg} / \mathrm{m}^{2}\right)\end{array}$ & Vùng ảnh hưởng \\
\hline \multicolumn{5}{|c|}{ Sụp cố xảy ra trùng với thời điểm pha triều lên } \\
\hline 1 & $1 \mathrm{~h}$ & Lên phía Bắc & $0,016-0,017$ & $\begin{array}{l}\text { Từ vị trí xảy ra sự cố mở rộng lên phía Bắc cách bờ } \\
\text { khoảng } 1 \text { km }\end{array}$ \\
\hline 2 & $6 \mathrm{~h}$ & Lên phía Bắc & $11,3 \times 10^{-4}$ & $\begin{array}{l}\text { Từ vị trí xảy ra sự cố mở rộng lên phía Bắc cách bờ } \\
\text { khoảng } 10 \text { km }\end{array}$ \\
\hline 3 & $12 \mathrm{~h}$ & $\begin{array}{l}\text { Mở rộng lên phía } \\
\text { Bắc, sang phía Tây } \\
\text { và xuống phía Nam }\end{array}$ & $5,5 \times 10^{-4}$ & $\begin{array}{l}\text { Phạm vi mở rộng từ bờ lên hết biên phía Bắc, sang } \\
\text { phía Tây khoảng } 11 \mathrm{~km} \text { và xuống phía Nam khoảng } \\
9 \mathrm{~km}\end{array}$ \\
\hline 4 & $24 \mathrm{~h}$ & $\begin{array}{l}\text { Mở rộng ra khu vực } \\
\text { xung quanh đảo }\end{array}$ & $2,5 \times 10^{-4}$ & $\begin{array}{l}\text { Hầu như toàn bộ phạm vi tính toán, chỉ một khu vực } \\
\text { nhỏ không bị ảnh hưởng nằm ở góc phía Đông Nam } \\
\text { của miền tính - cách bờ khoảng } 9 \mathrm{~km}\end{array}$ \\
\hline 5 & $36 \mathrm{~h}$ & $\begin{array}{l}\text { Mở rộng ra khu vực } \\
\text { xung quanh đảo }\end{array}$ & $15 \times 10^{-5}$ & Toàn bộ phạm vi tính toán \\
\hline \multicolumn{5}{|c|}{ Sụ̂ cố xảy ra trùng với thời điểm pha triều xuống } \\
\hline 6 & $1 \mathrm{~h}$ & $\begin{array}{l}\text { Về phía Tây Tây } \\
\text { Nam }\end{array}$ & $0,027-0,028$ & $\begin{array}{l}\text { Từ bờ ra phía ngoài khoảng 1,5km - về phía Tây } \\
\text { của đảo }\end{array}$ \\
\hline 7 & $6 \mathrm{~h}$ & Xuống phía Nam & $\begin{array}{l}1,3 \times 10^{-3} \\
1,4 \times 10^{-3}\end{array}$ & $\begin{array}{l}\text { Từ bờ ra phía tây của đảo khoảng } 2,5 \mathrm{~km} \text { và kéo dài } \\
\text { xuống phía Nam cách bờ khoảng } 6 \mathrm{~km}\end{array}$ \\
\hline 8 & $12 \mathrm{~h}$ & $\begin{array}{l}\text { Về phía Tây và phía } \\
\text { Bắc }\end{array}$ & $6,1 \times 10^{-4}$ & $\begin{array}{l}\text { Bao quanh đảo từ phía Bắc sang phía Tây và phía } \\
\text { nam - từ bờ ra phía ngoài khoảng } 6-9 \mathrm{~km} \text {; Một phần } \\
\text { nhỏ lan ra phía Đông của Đảo - từ bờ ra phía ngoài } \\
\text { khoảng } 5 \mathrm{~km}\end{array}$ \\
\hline 9 & $24 \mathrm{~h}$ & $\begin{array}{l}\text { Về phía Bắc Tây } \\
\text { Bắc }\end{array}$ & $2,5 \times 10^{-4}$ & $\begin{array}{l}\text { Toàn bộ khu vực góc } 1 / 4 \text { phía Tây Bắc của Đảo, một } \\
\text { phần bao xung quanh đảo-từ bờ ra phía ngoài } \\
\text { khoảng } 4-5 \mathrm{~km}\end{array}$ \\
\hline 10 & $36 \mathrm{~h}$ & $\begin{array}{l}\text { Mở rộng ra phía } \\
\text { Đông }\end{array}$ & $15 \times 10^{-5}$ & $\begin{array}{l}\text { Hầu như toàn bộ phạm vi tính toán, chỉ một khu vực } \\
\text { nhỏ không bi ảnh hưởng nằm ở góc phía Đông Nam } \\
\text { của miền tính - cách bờ khoảng } 10 \mathrm{~km}\end{array}$ \\
\hline
\end{tabular}


Gió hướng Tây Nam: với kịch bản sự cố tràn dầu $\mathrm{DO}$ xảy ra khi trường gió có hướng là Tây Nam với tốc độ là $4 \mathrm{~m} / \mathrm{s}$, khối lượng dầu tràn là 100 tấn. Vệt dầu chỉ ảnh hưởng trong phạm vi tính toán khoảng 14 ngày khi sự cố xảy ra vào thời điểm pha triều lên và 12 ngày khi sự cố xảy ra vào thời điểm pha triều xuống. Các đặc trưng (hàm lượng, hướng di chuyển, vùng ảnh hưởng) của vệt dầu biến đổi theo thời gian được thể hiện trong hình 9 và bảng 3 .

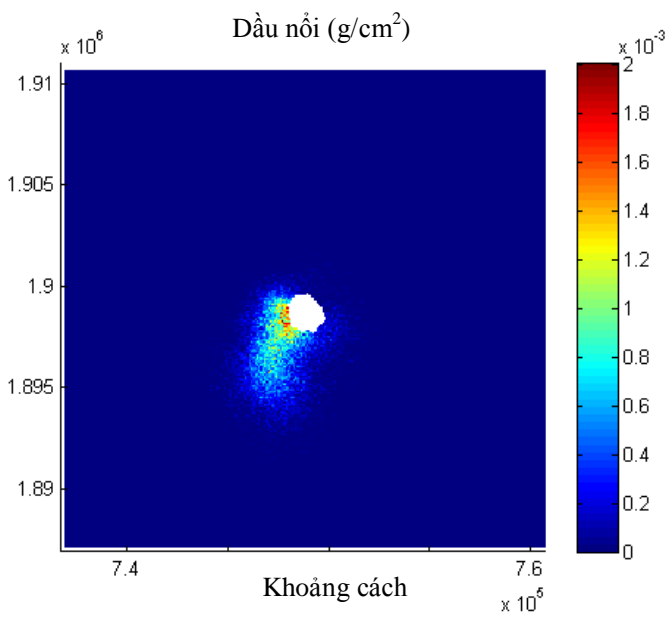

(a)

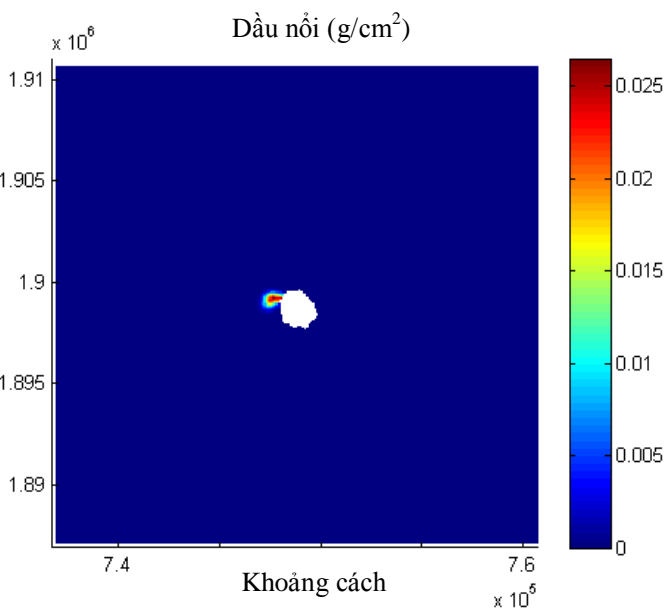

(b)

Hình 9. Sự cố tràn dầu (hướng gió Tây Nam, pha triều xuống) sau 1 giờ (a) và sau 6 giờ (b)

Bảng 3. Các đặc trưng của vệt dầu với trường hợp tính cho hướng gió Tây Nam $\left(225^{0}\right)$

\begin{tabular}{|c|c|c|c|c|}
\hline TT & $\begin{array}{l}\text { Thò̀i } \\
\text { gian }\end{array}$ & $\begin{array}{l}\text { Hướng di chuyển } \\
\text { của vệt dầu }\end{array}$ & $\begin{array}{l}\text { Hàm lượng dầu } \\
\max \left(\mathbf{k g} / \mathrm{m}^{2}\right)\end{array}$ & Vùng ảnh hưởng \\
\hline \multicolumn{5}{|c|}{ Sự cố xảy ra trùng với thời điểm pha triều lên } \\
\hline 1 & $1 \mathrm{~h}$ & Lên phía Bắc & 0,03 & $\begin{array}{l}\text { Từ vị trí xảy ra sự cố mở rộng lên phía Bắc cách bờ } \\
\text { khoảng } 1 \mathrm{~km}\end{array}$ \\
\hline 2 & $6 \mathrm{~h}$ & $\begin{array}{l}\text { Lên phía Bắc, } \\
\text { và phía Tây Nam }\end{array}$ & $16,5 \times 10^{-4}$ & $\begin{array}{l}\text { Phạm vi từ phía Bắc sang phía Tây xung quanh đảo } \\
\text { - cách bở khoảng 5-6 km }\end{array}$ \\
\hline 3 & $12 \mathrm{~h}$ & $\begin{array}{l}\text { Mở rộng ra xung } \\
\text { quanh đảo }\end{array}$ & $7,1 \times 10^{-4}$ & $\begin{array}{l}\text { Xung quanh đảo: từ bờ lên hết biên phía Bắc và } \\
\text { phía Nam; từ bờ ra phía ngoài khoảng } 10 \mathrm{~km} \text { về } \\
\text { phía Tây của đảo và khoảng } 7 \mathrm{~km} \text { về phía Đông của } \\
\text { đảo }\end{array}$ \\
\hline 4 & $24 \mathrm{~h}$ & $\begin{array}{l}\text { Mở rộng ra xung } \\
\text { quanh đảo }\end{array}$ & $2,2 \times 10^{-4}$ & Hầu hết phạm vi tính toán \\
\hline 5 & $36 \mathrm{~h}$ & $\begin{array}{l}\text { Mở rộng ra xung } \\
\text { quanh đảo }\end{array}$ & $15 \times 10^{-5}$ & Hầu hết phạm vi tính toán \\
\hline \multicolumn{5}{|c|}{ Sụp cố xảy ra trùng với thời điểm pha triều xuống } \\
\hline 7 & $1 \mathrm{~h}$ & $\begin{array}{l}\text { Về phía Tây Tây } \\
\text { Nam }\end{array}$ & $0,025-0,026$ & $\begin{array}{l}\text { Từ bờ ra phía ngoài khoảng } 1 \text { km - về phía Tây của } \\
\text { Đảo }\end{array}$ \\
\hline 8 & $6 \mathrm{~h}$ & $\begin{array}{l}\text { Về phía Nam và } \\
\text { Đông }\end{array}$ & $2,0 \times 10^{-3}$ & $\begin{array}{l}\text { Khu vực từ bờ xuống phía Nam của đảo- cách bờ } \\
\text { khoảng } 6 \mathrm{~km} \text {; Xung quanh đảo-từ bờ ra phía ngoài } \\
\text { khoảng } 1-2 \mathrm{~km} \text {. }\end{array}$ \\
\hline 9 & $12 \mathrm{~h}$ & $\begin{array}{l}\text { Mở rộng xung } \\
\text { quanh đảo }\end{array}$ & $5,5 \times 10^{-4}$ & $\begin{array}{l}\text { Xung quanh dảo - từ bờ ra phía ngoài khoảng } 7 \text { - } \\
10 \mathrm{~km}\end{array}$ \\
\hline 10 & $24 \mathrm{~h}$ & $\begin{array}{l}\text { Mở rộng xung } \\
\text { quanh đảo }\end{array}$ & $2,5 \times 10^{-4}$ & Hầu như toàn bộ khu vực tính toán \\
\hline 11 & $36 \mathrm{~h}$ & $\begin{array}{l}\text { Mở rộng xung } \\
\text { quanh đảo }\end{array}$ & $1,2 \times 10^{-4}$ & Hầu như toàn bộ khu vực tính toán \\
\hline
\end{tabular}




\section{KẾT LUẬN}

Mô hình Delft3D đã được sử dụng để mô phỏng các kịch bản tràn dầu theo các hướng gió khu vực đảo Cồn Cỏ. Theo kết quả nghiên cứu cho thấy xu thế vệt dầu nổi phụ thuộc rõ rệt vào các pha triều (lên và xuống). Trong pha triều lên vệt dầu ảnh hưởng từ 9 ngày đên 14 ngày và trong pha triều xuông vệt dâu ảnh hưởng từ 6 ngày đên 14 ngày. Với trường hợp gió hướng Đông Bắc, thời gian xảy ra sự cố trùng với pha triều xuống, vệt dầu có xu hướng mở rộng ra phía Bắc và phía Đông của đảo. Trường hợp gió hướng Nam, thời gian xảy ra sự cố trùng với pha triều lên, sau 1 ngày vệt dầu mở rộng toàn bộ xung quanh đảo. Trường hợp gió hướng Tây Nam, thời gian xảy ra sự cố trùng với pha triều xuống, sau 6 giờ vệt dầu mở rộng về phía Nam và phía Đông của đảo. Tuy nhiên độ chính xác của mô hình phụ thuộc nhiều vào các yếu tố khí tượng và trường độ sâu. Trong nghiên cứu tiếp theo những hạn chế này cần được khắc phục để nâng cao độ chính xác của mô hình.
Lời cảm ơn: Nhóm tác giả trân trọng cảm ơn Ban chủ nhiệm đề tài "VATS 06.03/12-13: Nghiên cứu bản chất hoàn luu ven đảo tại một sô đảo tiền tiêu trên vịnh Bắc Bộ phuc vu bảo vệ môi truờng, sinh thái và phát triển bền vũng" (2012-2013) đã tạo điều kiện cho việc hoàn thành công trình này.

\section{TÀI LIỆU THAM KHẢO}

1. Trần Anh Tú, Vũ Duy Vĩnh, Nguyễn Hũu Củ, 2008. Mô phỏng quá trình tràn dầu khu vực đảo Bạch Long Vĩ bằng mô hình delft3D. Tuyển tập Tài nguyên và môi trường biển, Tập XIII. Nxb. Khoa học và Kỹ thuật Hà Nội. Tr. 342-351.

2. WL|Delft Hydraulics, 1999. Delft3DFLOW User Manual Version 3.05, Delft3D

- Waq User Manual Version 3.01, Delft3D - Part User Manual Version 1.0 WL| Del 'ft Hydraulics, Delft, Netherlands.

3. http://energyinasiablog.com

4. http://www.gebco.net/data_and_products/gridded_bathymetry_data/

\title{
SIMULATION OF SOME OIL SPILL SCENARIOS IN CON CO ISLAND AREA
}

\author{
Tran Anh Tu, Le Duc Cuong
}

Institute of Marine Environment and Resources-VAST

\begin{abstract}
The Con Co Island plays an important role in the economic and security development strategy of Vietnam. The need for petroleum consume is more increasing in the world leading to the increase of petroleum transportation. Located near the petroleum transport line from Middle East to North East Asia, Con Co Island will be affected if oil spills happen. By using Delft3D model and nesting technique, some scenarios of oil spill (100 tons) in different wind directions in Con Co area are simulated. Calculating results show that, with the North-East wind case, the oil slick spreads in 9-14 days; in the case of southern wind, oil slick spreads in 6-9 days and the case of South Wets, oil slick spread in 12-14 days. The results are reference for marine management agencies and related sectors.
\end{abstract}

Keywords: Oil spill, scenarios. 